\title{
Desert Hedgehog/Patched 1 signaling specifies fetal Leydig cell fate in testis organogenesis
}

\author{
Humphrey Hung-Chang Yao, ${ }^{1}$ Wendy Whoriskey, ${ }^{2}$ and Blanche Capel ${ }^{1,3}$ \\ ${ }^{1}$ Department of Cell Biology, Duke University Medical Center, Durham, North Carolina 27710, USA; ${ }^{2}$ Curis, Inc., \\ Cambridge, Massachusetts 02138, USA
}

\begin{abstract}
Establishment of the steroid-producing Leydig cell lineage is an event downstream of Sry that is critical for masculinization of mammalian embryos. Neither the origin of fetal Leydig cell precursors nor the signaling pathway that specifies the Leydig cell lineage is known. Based on the sex-specific expression patterns of Desert Hedgehog (Dhh) and its receptor Patched 1 (Ptch1) in XY gonads, we investigated the potential role of DHH/PTCH1 signaling in the origin and specification of fetal Leydig cells. Analysis of $\mathrm{Dhh}^{-/-} \mathrm{XY}$ gonads revealed that differentiation of fetal Leydig cells was severely defective. Defects in Leydig cell differentiation in $\mathrm{Dhh}^{-/-} \mathrm{XY}$ gonads did not result from failure of cell migration from the mesonephros, thought to be a possible source of Leydig cell precursors. Nor did DHH/PTCH1 signaling appear to be involved in the proliferation or survival of fetal Leydig precursors in the interstitium of the XY gonad. Instead, our results suggest that DHH/PTCH1 signaling triggers Leydig cell differentiation by up-regulating Steroidogenic Factor 1 and P450 Side Chain Cleavage enzyme expression in Ptch1-expressing precursor cells located outside testis cords.
\end{abstract}

[Key Words: Desert Hedgehog; Patched 1; Leydig; mesonephros; testis; organogenesis]

Received February 1, 2002; revised version accepted April 10, 2002.

A critical event in testis organogenesis is the specification of somatic cell lineages including Sertoli cells, peritubular myoid cells, and Leydig cells. Specification of these lineages is crucial for the establishment of testis morphology and the production of hormones. A single gene on the Y chromosome, Sry (s ex-determining region of the $\underline{Y}$ chromosome), is believed to induce a cascade of signaling pathways for the differentiation of these somatic cell lineages (Gubbay et al. 1990; Koopman et al. 1991). Autonomous expression of Sry in somatic cells in the XY gonad leads to differentiation of Sertoli cells (Albrecht and Eicher 2001). Differentiating gonadal cells induce migration of cells from the mesonephros into the gonad. The migrating cells contribute to precursors of the peritubular myoid and vascular cell lineages (Martineau et al. 1997; Capel et al. 1999; Tilmann and Capel 1999|. Differentiation of peritubular myoid cells and the consequent formation of testis cords are regulated by Desert hedgehog (DHH), a signaling protein produced by Sertoli cells (Clark et al. 2000; Pierucci-Alves et al. 2001). Fetal Leydig cells are first identifiable within the

${ }^{3}$ Corresponding author.

E-MAIL b.capel@cellbio.duke.edu; FAX (919) 684-5481.

Article and publication are at http://www.genesdev.org/cgi/doi/10.1101/ gad.981202. interstitium of the XY gonad (between testis cords) when they express P450 Side Chain Cleavage (Scc) enzyme and other steroidogenic enzymes required for the production of androgens.

The specification of adult Leydig cells has been studied extensively (Habert et al. 2001). Adult Leydig cells are believed to be a separate population of steroidogenic cells that arise from adult peritubular mesenchymal cells (Ariyaratne et al. 2000). They are believed to be completely independent of the population of fetal Leydig cells responsible for initial masculinization of the embryo. The origin of fetal Leydig cells is unknown. During fetal life, Leydig cell precursors could arise from one or both of two possible sources: the mesonephros or the coelomic epithelium. When gonads from 11.5 days postcoitum (dpc) embryos were grafted to mesonephroi from mice carrying transgenic markers such as $\beta$-galactosidase ( $\beta$-gal) or GFP, the markers were found in some of the peritubular myoid cells and other interstitial cells of the testis (Buehr et al. 1993; Merchant-Larios et al. 1993; Nishino et al. 2000). Some migratory mesonephric cells acquired ultrastructural features of steroidogenic Leydig cells (Merchant-Larios and Moreno-Mendoza 1998). A small population of these migrating cells differentiated into Leydig cells when cultured in vitro (Nishino et al. 2001). However, when the XY gonad was separated from 
the mesonephros at $11.5 \mathrm{dpc}$ and cultured alone (Merchant-Larios et al. 1993) or when XY gonads were grafted to embryonic hind limbs at $11.5 \mathrm{dpc}$ and subsequently cultured (Moreno-Mendoza et al. 1995), differentiation of Leydig cells proceeded normally. The results of these two experiments suggest that most Leydig precursors are already present in the gonad by $11.5 \mathrm{dpc}$. Another possible source of Leydig cell precursors is the coelomic epithelium that covers the entire coelomic surface of the gonad. Both proliferation studies (Schmahl et al. 2000) and DiI lineage tracing experiments (Karl and Capel 1998) revealed that coelomic epithelial cells in XY gonads proliferate rapidly between 11.5 and $12.5 \mathrm{dpc}$ and contribute many interstitial cells to the developing testis. The fate of these cells has not been defined. The signals that induce differentiation of fetal Leydig cells are also unknown. At present only a negative regulator of Leydig cell differentiation (Wnt4) has been identified (Vainio et al. 1999). Expression of the hedgehog receptor, Patched 1 (Ptch1), throughout the cells of the interstitium in $12.5 \mathrm{dpc}$ XY gonads suggested that DHH/PTCH1 signaling might function in Leydig cell differentiation in addition to its role in signaling between Sertoli and peritubular myoid cells (Bitgood et al. 1996). To determine the role of DHH/PTCH1 signaling in Leydig cell differentiation, we explored the temporal and spatial expression patterns of Dhh, Ptch1, and Scc, and analyzed gonads from $D h h^{-/-} \mathrm{XY}$ embryos. Here we show that disruption of DHH/PTCH1 signaling in $D h^{-/-}$mice results in defects of fetal Leydig cell differentiation, whereas it has no effect on mesonephric cell migration or on the establishment of the interstitial cell population. These results suggest that $\mathrm{DHH} / \mathrm{PTCH} 1$ signaling does not affect the origin of fetal Leydig precursors, but instead, operates later to specify the Leydig cell lineage by up- regulating Steroidogenic Factor 1 (Sf1) and Scc expression in Ptch1-expressing precursor cells located outside testis cords.

\section{Results}

Temporal and spatial expression of Dhh, Ptch1, and Scc in testis organogenesis

To determine whether fetal Leydig cells might be targets of DHH signaling, we first detailed the expression patterns of Dhh, its receptor, Ptch1, and a Leydig cell marker Scc (Rouiller et al. 1990) in XY gonads from 11.5 to $13.5 \mathrm{dpc}$, the period during which the differentiation of fetal Leydig cells occurs. Expression of Dhh began at $11.5 \mathrm{dpc}$ and continued afterward in the Sertoli cell lineage as previously described (Fig. 1; Bitgood et al. 1996). Analyzing $\beta$-galactosidase activity in Ptch ${ }^{t m 1 M p s}$ $\left(P_{t c h}{ }^{\text {LacZ }}\right)$ XY gonads, we found that $P t c h^{\text {LacZ }}$ was not expressed at $11.5 \mathrm{dpc} \mathrm{XY}$ gonads, but was prominently expressed in the interstitial space between testis cords in 12.5 and 13.5 dpc XY gonads (Fig. 1). Ptch ${ }^{\text {LacZ }}$ expression was also found around the mesonephric tubules in the anterior part of the mesonephros from 11.5 to $13.5 \mathrm{dpc}$. We compared $P t c h^{L a c Z}$ expression with Scc expression to determine whether Ptch ${ }^{\text {LacZ }}$-expressing cells became Scc-positive. At $12.5 \mathrm{dpc}$, the majority of interstitial cells were $P t c h^{\text {LacZ }}$-positive and only a small population of them expressed Scc (Fig. 1). In 13.5 dpc XY gonads, a much larger percentage of $\mathrm{Ptch}^{\mathrm{LacZ}}$-expressing cells were also expressing Scc (Fig. 1, bottom panels). Neither Ptch ${ }^{\text {LacZ }}$ nor Scc was expressed in the coelomic epithelium of XY gonads (Fig. 1, bottom panels) or in endothelial cells of the vasculature (data not shown). Patched 2, another mammalian hedgehog receptor (Carpenter et al.
Figure 1. Expression patterns of $D h h$ (dark purple), Ptch1 (blue), and the Leydig cell marker $S c c$ (red) in XY gonads from $11.5 \mathrm{dpc}$ to $13.5 \mathrm{dpc}$. Expression of Dhh and $S c c$ were detected by whole-mount in situ hybridization. Ptch1 expression was detected by analyzing $\beta$-galactosidase activity in the Ptch ${ }^{t m 1 M p s} \mathrm{XY}$ gonads. Sections of $13.5 \mathrm{dpc}$ whole-mount samples are shown at the bottom to confirm the cellspecific expression patterns of Dhh, Ptch1, and Scc in the gonads. CE, coelomic epithelium; G, gonad; M, mesonephros; TC, testis cords.

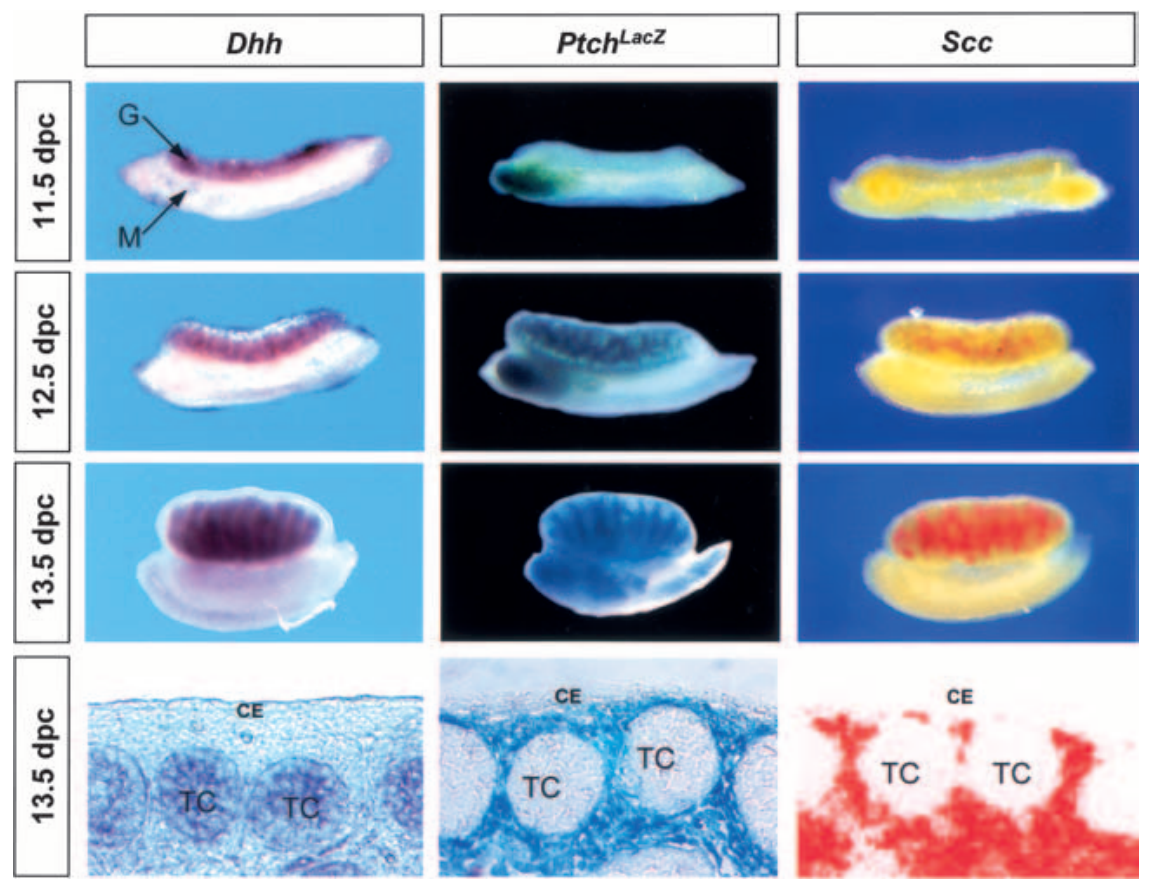


1998), was not expressed in XY gonads during this time period (data not shown). Other hedgehog genes such as Sonic Hedgehog and Indian Hedgehog are not expressed in the gonad (Bitgood and McMahon 1995).

\section{Defects in differentiation of fetal Leydig cells} in $\mathrm{Dhh}^{-/-}$XY gonads

The expression patterns of Dhh and its receptor, Ptch1, indicated that $\mathrm{DHH}$ signaling could be involved in the early development of Leydig cells. To investigate whether differentiation of fetal Leydig cells was affected by loss of DHH signaling, we analyzed the expression of Scc in 13.5-14.5 dpc $D h h^{+/+}, D h h^{+/-}$, and $D h h^{-/-} \mathrm{XY}$ gonads (Clark et al. 2000). No differences were noted between $D h^{+/+}$and $D h h^{+/-}$samples. Representative $D h h^{+-}$samples are shown in Figures 2 and 3. At 13.5 dpc, expression of $S c c$ appeared in the center of all $D h h^{+/+}$and $D h h^{+/-}$gonads, whereas Scc expression was completely absent in $70 \%(7 / 10)$ of $\mathrm{Dhh}^{-1-}$ gonads (Fig. 2). By $14.5 \mathrm{dpc}$, Scc expression reached its peak in interstitial cells in $D h h^{+/+}$and $D h h^{+/-}$gonads. However, only sparse staining for Scc was seen in the majority of 14.5 dpc $D h h^{-/-}$gonads (Fig. 2). It is known that the expression of Scc is under the regulation of SF1 (Clemens et al. 1994; Hatano et al. 1994). We performed immunocytochemistry for SF1 on $13.5 \mathrm{dpc}$ XY gonads after in situ hybridization for Scc to verify that Scc-expressing cells were also SF1-positive. We found that all Scc-expressing cells (Fig. 3A, red cells outside of testis cords) showed strong nuclear staining for SF1 (Fig. 3A, green stain). In $D h h^{-1-}$ gonads, the number of interstitial Leydig cells with strong nuclear SF1 staining was dramatically decreased compared to $\mathrm{Dhh}^{+/+}$and $\mathrm{Dhh}^{+/-}$gonads (Fig. $3 \mathrm{~B}, \mathrm{C}$, arrows). However, interstitial cells with weak nuclear SF1 staining were still present in $D h h^{-/-}$gonads in normal numbers (Fig. 3C, arrowheads). Expression of

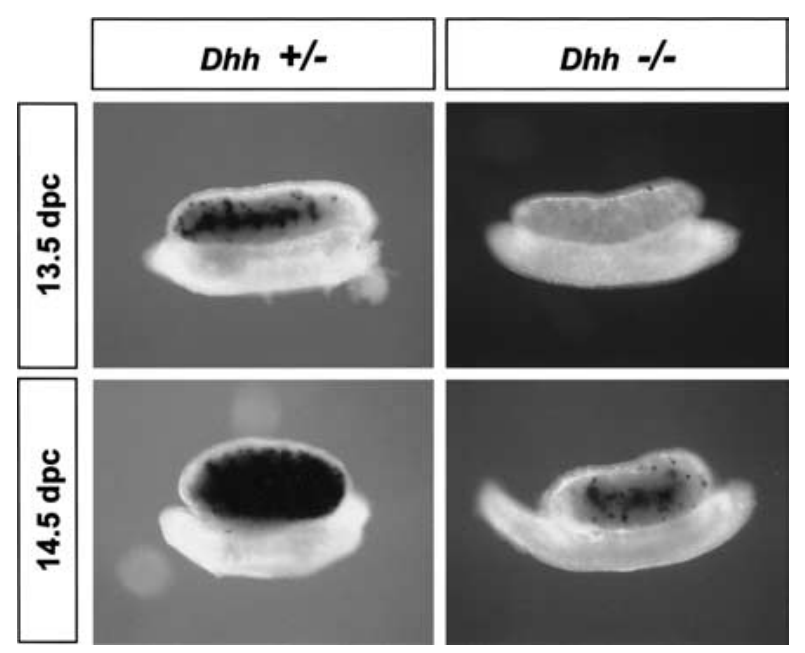

Figure 2. Expression of $S c c$ in $D h h^{+/-}$and $D h h^{-/-} \mathrm{XY}$ gonads. The mRNA for the Leydig cell marker $S c c$ (black stain) is present at 13.5 and $14.5 \mathrm{dpc}$ in $D h h^{+/+}$(data not shown) and $D h h^{+/-}$ but is reduced or absent in $D h h^{-/-} \mathrm{XY}$ gonads.
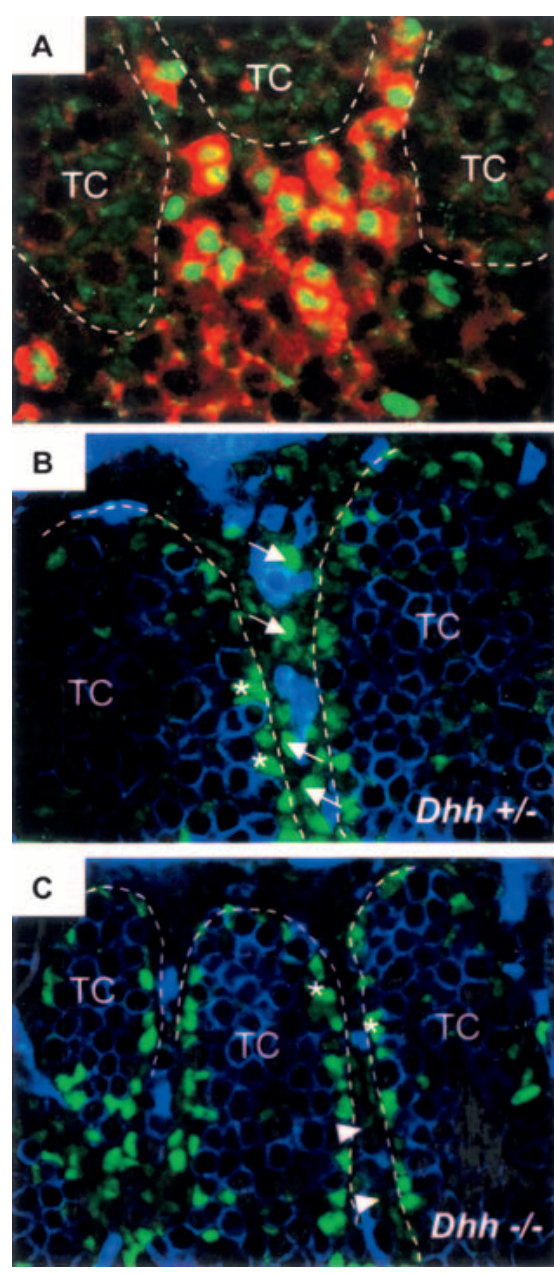

Figure 3. Expression of SF1 and Scc in $13.5 \mathrm{dpc} \mathrm{Dhh}^{+/-}$and $D h h^{-/-}$XY gonads. (A) Colocalization of SF1 (green nuclear staining) and Scc (red cytoplasmic staining) in Leydig cells in normal 13.5 dpc XY gonads by immunocytochemistry for SF1 and in situ hybridization for Scc. (B) Strong nuclear SF1 staining (arrows) in Leydig cells in $\mathrm{Dhh}^{+-}$gonads. (C) Absence of strong nuclear SF1 staining in Leydig cells in $\mathrm{Dhh}^{-1-}$ gonads. Weak nuclear SF1 staining was still present (arrowheads). SF1 staining was also detected in Sertoli cells (asterisks) in testis cords (TC, outlined by dotted lines). Germ cells and endothelial cells were stained with an anti-PECAM antibody (blue staining in $B$ and $C)$.

SF1 in Sertoli cells in testis cords was not affected by disruption of DHH signaling (Fig. 3B,C, asterisks).

\section{Normal mesonephric cell migration in $\mathrm{Dhh}^{-/-}$ $X Y$ gonads}

One of the cellular events downstream of Sry is migration of interstitial cells from the mesonephros into the gonad between 11.5 and 12.5 dpc (Capel et al. 1999; Tilmann and Capel 1999|. Because most interstitial cells express Ptch $^{\text {LacZ }}$ at $12.5 \mathrm{dpc}$ (Fig. 1), we investigated whether Dhh signaling regulates mesonephric cell migration. Ptch ${ }^{\text {LacZ }}$ expression showed a unique pattern 
during the period when mesonephric cell migration occurs. At $11.5 \mathrm{dpc}, \mathrm{Ptch}^{\text {LacZ }}$ expression was observed only around the mesonephric tubules at the anterior part of the mesonephros but not in gonads of either sex (Fig. 1). As the development of gonads proceeded to $12.0 \mathrm{dpc}$, Ptch ${ }^{\text {LacZ }}$ expression appeared in the interstitium in the anterior part the XY gonad close to the mesonephric tubules (Fig. 4A). At 12.25 dpc, Ptch ${ }^{\text {LacZ }}$ expression in the $\mathrm{XY}$ gonad extended anteriorly and posteriorly (Fig. 4A). By $12.5 \mathrm{dpc}$, the entire interstitium of the XY gonad expressed Ptch ${ }^{\text {LacZ }}$, except for the most posterior tip of the gonad (Fig. 1). No Ptch ${ }^{\text {LacZ }}$ expression was found in XX gonads at any stage examined (data not shown).

This unique pattern of $\mathrm{Ptch}^{\text {LacZ }}$ expression (Fig. 4A) suggested that the $\mathrm{DHH} / \mathrm{PTCH} 1$ signaling pathway might induce migration of Ptch1-expressing cells from the mesonephros into the interstitium of the XY gonad, beginning near the anterior end of the gonad. To test this hypothesis, we assembled two different recombinant organ cultures at $11.25 \mathrm{dpc}$. In the first recombinant culture (Fig. 4B), we assembled a wild-type gonad with a Ptch ${ }^{\text {LacZ }}$ mesonephros. We reasoned that if $\operatorname{Ptch}^{\text {LacZ }}$-expressing cells derive from the mesonephros, we should observe $\beta$-gal-positive cells in the wild-type gonad after migration has taken place. In the second recombinant culture (Fig. 4C), we assembled the reciprocal combination with a Ptch ${ }^{\text {LacZ }}$ gonad apposed to a wild-type mesonephros. After culture for $30 \mathrm{~h}$ (corresponding to $\sim 12.5$ dpc in vivo), samples were stained for $\beta$-gal. We found no $\beta$-gal staining in the interstitium of the wild-type gonad in the first recombinant culture (Fig. 4B), suggesting that few if any cells that have migrated from the mesonephros during this period of culture express $P t c h^{L a c Z}$. In the second recombinant culture with a $P t c h^{L a c Z}$ gonad and a wild-type mesonephros, $\beta$-gal staining appeared in the interstitium of all Ptch ${ }^{\text {LacZ }}$ gonads (Fig. 4C), suggesting that Ptch ${ }^{\text {LacZ }}$ expression is induced in cells already present in the gonad by $11.25 \mathrm{dpc}$.

To further test the possibility that DHH/PTCH1 signaling was involved in mesonephric cell migration, we assembled an $11.5 \mathrm{dpc} D \mathrm{Dh}^{+/+}, D \mathrm{Dh}^{+/-}$, or $D \mathrm{hh}^{-/-} \mathrm{XY}$ gonad apposed to an $11.5 \mathrm{dpc}$ mesonephros expressing GFP and compared the migration of GFP-expressing cells in the presence and absence of $\mathrm{DHH}$ signaling. We found that GFP-expressing cells migrated from the mesonephros into the XY gonad in a similar pattern in $D h h^{+/+}$(data not shown), $D h h^{+/-}$, and $D h h^{-/-}$gonads (Fig. 4D, red arrows). Analysis of Scc expression in these samples revealed that despite normal mesonephric cell migration, expression of Scc is completely absent in $D h h^{-1-} \mathrm{XY}$ gonads compared to $D h h^{+/+}$and $D h h^{+/-}$gonads (Fig. 4D, red staining).

\section{Stage-specific effects of the hedgehog inhibitor} cyclopamine on Leydig cell differentiation

To determine whether $\mathrm{DHH} / \mathrm{PTCH} 1$ signaling regulates the earliest stages of Leydig cell differentiation or later

Figure 4. DHH/PTCH1 signaling is not responsible for induction of mesonephric cell migration into XY gonads. (A) Analysis of Ptch $^{\text {LacZ }}$ expression in 12.0 and 12.25 dpc XY gonads. (B) Recombinant organ culture using a wild-type gonad apposed to a Ptch $^{\text {LacZ }}$ mesonephros. (C) Reciprocal organ culture with a $P t c h^{L a c Z}$ gonad apposed to a wild-type mesonephros. Recombinant organ cultures in both $B$ and $C$ were assembled at $11.25 \mathrm{dpc}$, cultured for $48 \mathrm{~h}$, and assayed for $P t c h^{L a c Z}$ expression. (D) Mesonephric cell migration and Scc expression in $\mathrm{Dhh}^{+/-}$and $\mathrm{Dhh}{ }^{-/-}$gonads: Recombinant gonad cultures were assembled with an $11.5 \mathrm{dpc} D h h^{+/-}$or $D h h^{-/-}$XY gonad apposed to an $11.5 \mathrm{dpc}$ mesonephros expressing GFP. Cell migration (green cell, red arrows) was detected $48 \mathrm{~h}$ after culture. Samples were fixed, and then expression of Scc was detected by in situ hybridization (red staining in gonads).

A

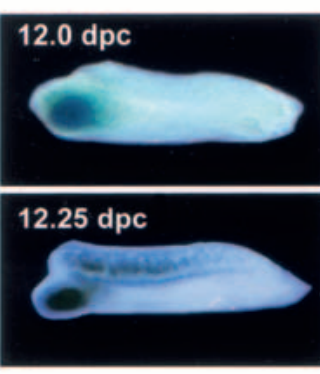

B
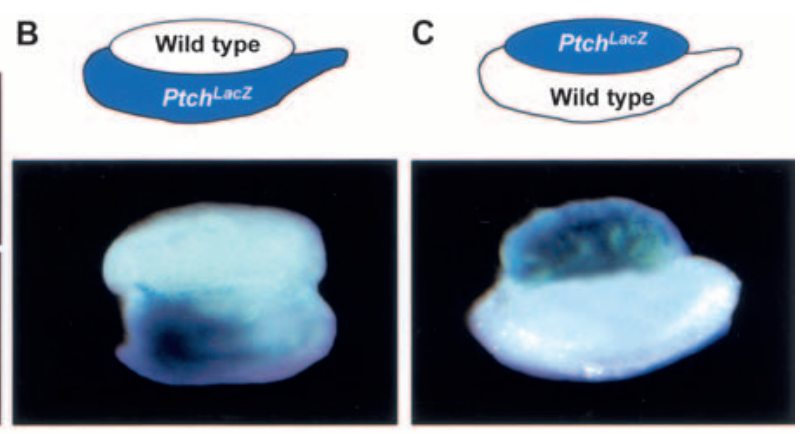

D Dhh+/-
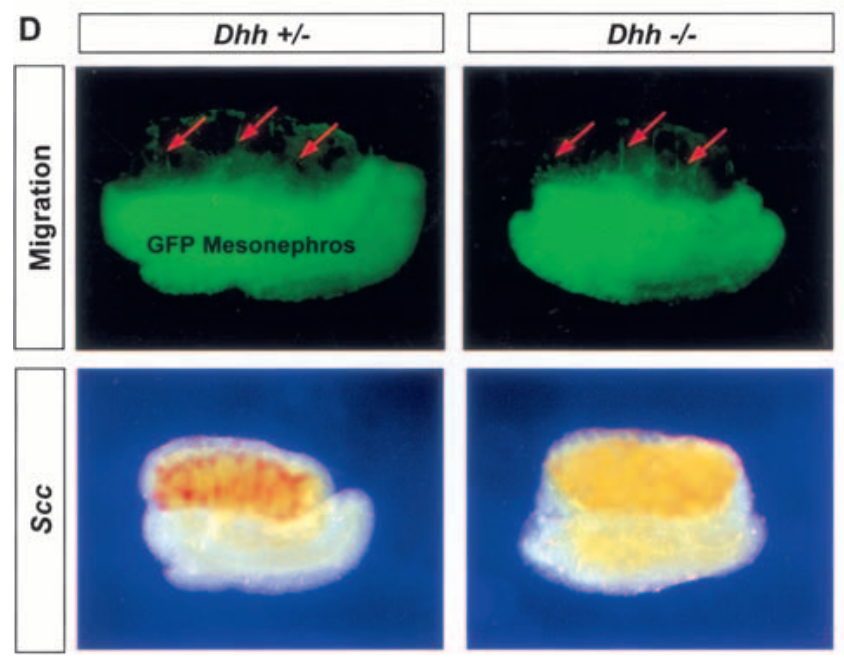
maintenance or expansion of the Leydig cell population, we examined Scc expression in gonad organ cultures in the presence and absence of a DHH signaling inhibitor, cyclopamine, introduced at $11.5 \mathrm{dpc}$ or $12.5 \mathrm{dpc}$. Cyclopamine inhibits hedgehog signaling by inactivating Smoothened, the first downstream signaling molecule after binding of hedgehog protein to its receptor, PTCH1 (Taipale et al. 2000). Scc was expressed normally in both 11.5 and $12.5 \mathrm{dpc}$ gonads after 24 -h culture in the absence of cyclopamine. When cyclopamine was added at $11.5 \mathrm{dpc}$, the expression of Scc in Leydig cells was completely inhibited. In contrast, addition of cyclopamine to cultures at $12.5 \mathrm{dpc}$ or $13.5 \mathrm{dpc}$ had no effect on Scc expression in Leydig cells (Fig. 5, black stain; 13.5 dpc data not shown).

To determine whether the loss of $\mathrm{DHH}$ signaling affected proliferation or maintenance of Leydig precursors, we examined cell proliferation using an antibody against phosphorylated Histone H3 (pHH3; Paulson and Taylor 1982; Hendzel et al. 1997; Saka and Smith 2001), and apoptosis, using LysoTracker reagent (Zucker et al. 1998, 1999), in 11.5 dpc gonad explants cultured for $40 \mathrm{~h}$ in the presence or absence of cyclopamine. We found a similar total number of $\mathrm{pHH} 3$-positive cells /cell counts from 10 serial sections) in gonads cultured in the absence or presence of cyclopamine (Fig. 6, arrows). Although normal apoptotic cells were detected in the Müllerian duct in the mesonephros at this stage (Roberts et al. 1999), no apoptotic cells were found in the gonadal region of samples cultured in the presence or absence of cyclopamine (Fig. 6, the gonad is outlined by a dotted line).

\section{Discussion}

It has been more than five decades since Jost first discovered that testosterone synthesized by the fetal testis is essential for differentiation of the Wölffian duct and

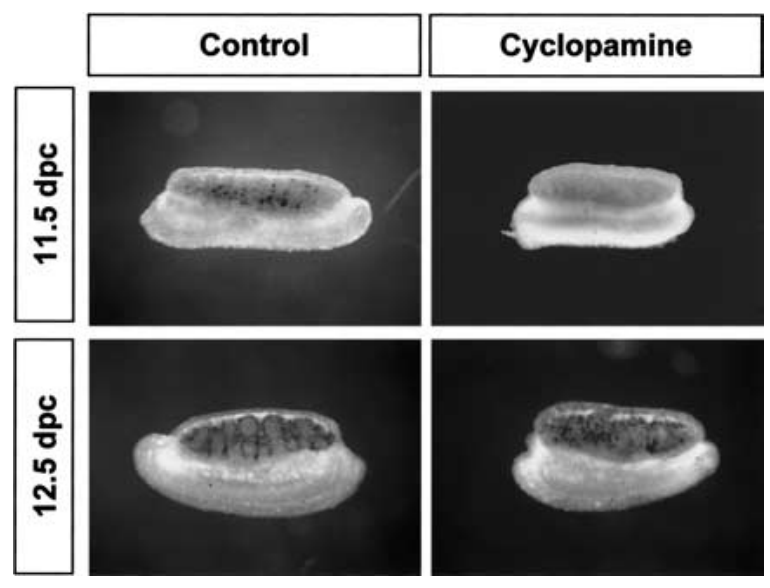

Figure 5. Stage-specific effects of the hedgehog inhibitor cyclopamine on expression of Scc mRNA in Leydig cells. XY gonads ( 11.5 or $12.5 \mathrm{dpc}$ ) were cultured in the presence or absence of cyclopamine $(25 \mu \mathrm{M})$ for $24 \mathrm{~h}$ followed by whole-mount in situ hybridization for Scc (black staining in gonads).

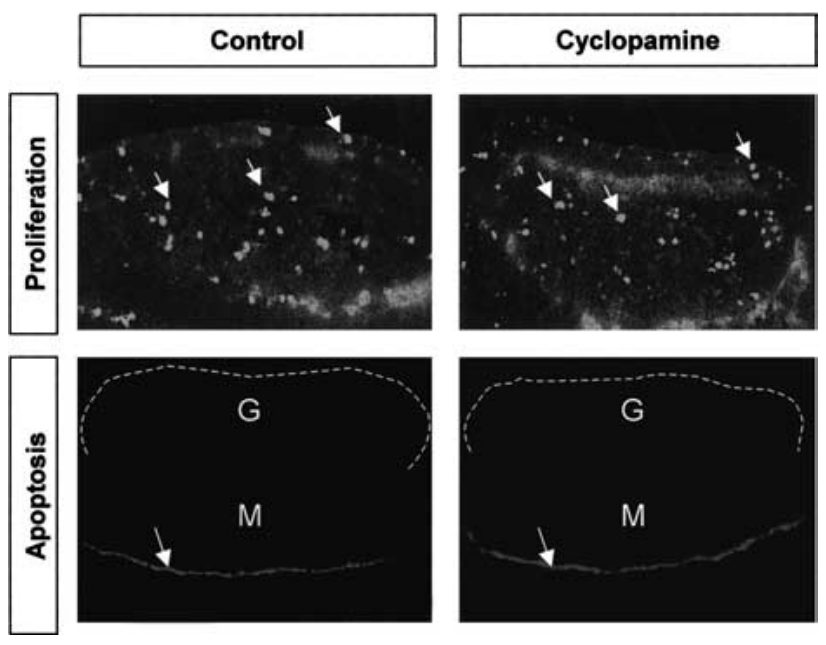

Figure 6. Effects of the hedgehog inhibitor cyclopamine on proliferation and apoptosis in $11.5 \mathrm{dpc}$ gonads. Gonads $(11.5$ dpc) were cultured for $24 \mathrm{~h}$ in the presence or absence of cyclopamine $(25 \mu \mathrm{M})$ followed by immunocytochemistry for phosphorylated Histone H3 (arrows) or LysoTracker staining for apoptosis (arrows indicate position of the Müllerian duct). G, gonad (outlined by a dotted line); M, mesonephros.

development of male secondary sex characteristics (Jost 1947). Here we report that DHH/PTCH1 signaling is a positive regulator of the differentiation of steroid-producing Leydig cells in the fetal testis. Dhh is expressed downstream of Sry, specifically in Sertoli cells inside testis cords (Bitgood et al. 1996), and is the only known mammalian hedgehog protein expressed in the gonad between 11.5 and $13.5 \mathrm{dpc}$. One of the hedgehog receptors, Ptch1, was known to be expressed in interstitial cell populations (Bitgood et al. 1996). Original generation of Dhh-null mice on a $129 / S_{V}$ genetic background resulted in defects in spermatogenesis but no defects in testis organogenesis and Leydig cell differentiation despite down-regulation of Ptch1 (Bitgood et al. 1996). However, transfer of the Dhh mutation to another genetic background resulted in discrete defects in development of the peritubular myoid cell lineage, leading to abnormal cord organization and loss of adult Leydig cells (Clark et al. 2000; Pierucci-Alves et al. 2001). We show here that it also results in a defect in differentiation of fetal Leydig cells.

Ptch1 is first expressed around the mesonephric tubules at the anterior end of the mesonephros. By 12.0 $\mathrm{dpc}$, interstitial cells toward the anterior end of the gonad begin to express Ptch1 under the positive regulation of DHH. Expression of Ptch1 gradually extends toward both anterior and posterior ends of the gonad. Despite the implications of this expression pattern, we find no evidence that $\mathrm{DHH}$ is involved in signaling for mesonephric cell migration. Nor does loss of Dhh appear to exert a detrimental effect on Sertoli differentiation, as MIS and Sox 9 expression in $\mathrm{Dhh}^{-1-}$ gonads and in cyclopamine treated gonads (Yao and Capel 2002) are normal.

Instead, this and previous data suggest that $\mathrm{DHH}$ is involved in signaling proximal cells to differentiate 
along specific pathways. For example, it has been shown that $\mathrm{DHH}$ influences the differentiation of peritubular myoid cells in Ptch1-expressing cells most proximal to the DHH signal (Clark et al. 2000; Pierucci-Alves et al. 2001). Here we show that DHH signals the Ptch1-expressing cells located slightly further away from the DHH-producing Sertoli cells to differentiate as Leydig cells. Although it appears that all Leydig cells express Ptch1, not all Ptch1-expressing cells differentiate as Leydig cells. This likely means that other signals combine with DHH signals to specify Leydig cell fate.

Leydig precursors responsive to the $\mathrm{DHH}$ signal may be set aside earlier by their lineage origin, or they may be specified among cells of the interstitium by the intersection of multiple signals. Some evidence suggests that Leydig cells and steroid cells of the adrenal share a common origin at $10.5 \mathrm{dpc}$ near the anterior end of the mesonephros (Hatano et al. 1996). If this is true, they must move into the gonad prior to $11.25 \mathrm{dpc}$ under the control of signals other than $\mathrm{DHH}$ or they would have been detected in our recombinant organ culture system. Another possibility is that Leydig cells do not have a discrete lineage origin: pluripotent cells may derive from the coelomic epithelium between 11.5 and $12.5 \mathrm{dpc}$ whose differentiation is under the control of combinatorial signals that intersect in the field of the gonad. This type of paradigm could suggest that the interstitial cells of the gonad are equivalent and plastic in the sense that, regardless of where they originate, they may follow one of several cell fates in the gonad. This decision could depend not on their lineage origin, but on their distance from other signaling cells or their spatial relationship to the vasculature or to other structural features of the gonad. Hedgehog signaling effects related to distance from the signal have been noted in many systems (Bumcrot and McMahon 1996; Neumann and Cohen 1997; Strigini and Cohen 1999; Vervoort 2000).

$\mathrm{DHH}$ does not regulate the size of the precursor population. We found that interstitial cells with low SF1 expression were still present in the $D h h^{-/}$gonads, which may account for morphological identification of fetal Leydig cells in electron micrographs in $\mathrm{Dhh}^{-1-}$ gonads (Clark et al. 2000). In previous work, we showed that low SF1-expressing cells derived from a second wave of proliferation in the coelomic epithelium (Schmahl et al. 2000). No difference in proliferation or apoptosis was observed in gonads cultured with the hedgehog inhibitor cyclopamine, suggesting that $\mathrm{DHH} / \mathrm{PTCH} 1$ signaling does not regulate proliferation or survival of fetal Leydig cell precursors as has been shown to occur in other systems (Cann et al. 1999; Oppenheim et al. 1999; Charrier et al. 2001). The time at which DHH affects Leydig differentiation, based on in vitro experiments using cyclopamine to block hedgehog signals, suggests that $\mathrm{DHH} /$ PTCH1 signaling specifies Leydig cell fate by early upregulation of SF1 and its target, Scc.

The failure of fetal Leydig cell differentiation provides an explanation for the feminized external genitalia phenotype of $D h^{-1-}$ XY mice (Clark et al. 2000) and a 46,XY partial gonad dysgenesis patient with a Dhh mutation
(Umehara et al. 2000). Both cases developed premature female external genitalia with a blind vagina. The internal accessory sex glands and ducts, whose development depends upon the proper amount of testosterone from fetal Leydig cells, are decreased in size, and the testes were undescended. The appearance of a few Leydig cells in $D h^{-/-}$gonads at later stages is not sufficient to rescue differentiation of secondary sex characteristics in $D h^{-/-}$ mice; however, it does suggest that other signaling pathways may partially compensate for loss of the DHH/ PTCH1 signaling pathway. Alternatively, a subpopulation of Leydig cells may derive independent of DHH/ PTCH1 signaling. We are conducting more experiments to explore the origin of Leydig cell precursors and the interaction between $\mathrm{DHH} / \mathrm{PTCH} 1$ and other signaling pathways.

\section{Materials and methods}

\section{Mouse strains}

The generation of Dhh-null mice was described previously, and original breeding mice for the Curis colony were kindly provided by Dr. Andrew McMahon (Harvard University, Cambridge, MA). Mice were bred on a mixed background of 129/SV, $C 57 B L / 6$, and Swiss Webster. The Dhh genotype was determined by polymerase chain reaction (PCR) of tail DNA. CD1 random-bred mouse strains (Charles River) were used for organ culture, immunocytochemistry, and in situ hybridization. GFP transgenic mice (Hadjantonakis et al. 1998) were used for migration studies. The Ptch ${ }^{t m 1 M p s}$ mice were generated as described by Goodrich et al. (1997) and were kindly provided by Dr. Matthew Scott of Stanford University.

\section{Organ culture}

Genital ridges (gonad plus mesonephros) from 11.25-11.5 dpc embryos $(0.5 \mathrm{dpc}$ represents noon of the day when the vaginal plug was detected) were obtained for organ culture. To determine the sex of 11.25-12.5 dpc embryos, we used a staining method (Palmer and Burgoyne 1991) to detect the presence of $\mathrm{XX}$-specific Barr bodies in the amnion of individual embryos. Genital ridges were cultured at $37^{\circ} \mathrm{C}$ with $5 \% \mathrm{CO}_{2} / 95 \%$ air on a $1.5 \%$ agar block for $48 \mathrm{~h}$ in Dulbecco's Minimal Eagle Medium (DMEM), supplemented with $10 \%$ fetal calf serum (Hyclone), and $50 \mu \mathrm{g} / \mathrm{mL}$ ampicillin. Cyclopamine $(25 \mu \mathrm{M}$, TRC Biomedical Research Chemicals) was added to the culture medium to inhibit the hedgehog signaling pathway. This concentration of cyclopamine represented the minimal concentration resulting in disruption of testis cord formation as determined previously (Yao and Capel 2002). An equivalent volume of methanol (solvent for cyclopamine) was added to other organ cultures as controls.

\section{Whole-mount in situ hybridization}

Samples were fixed overnight in $4 \%$ paraformaldehyde in PBS at $4^{\circ} \mathrm{C}$ and processed according to the method of Henrique et al. (1995). We used alkaline phosphatase-conjugated digoxigeninlabeled RNA probes for Dhh and Scc. Two different alkaline phosphatase substrates (NBT/BCIP for Dhh, Fast Red for Scc, Boehringer Mannheim) were used for color development. 
Double whole-mount in situ hybridization and immunocytochemistry

To double-label Scc (mRNA) and SF1 (protein) in the gonads, whole-mount in situ hybridization was performed as described above using Fast Red as the substrate for alkaline phosphate followed by immunocytochemistry against SF1. After fast red color development $(\sim 5 \mathrm{~h}$ at room temperature), samples were washed in PBS for 10 min and blocked in the blocking solution $(10 \%$ heat-inactivated goat serum and $0.1 \%$ Triton X-100 in PBS) for $1 \mathrm{~h}$ at room temperature. A rabbit polyclonal antibody against SF1 (1:200) was added to the blocking solution and samples were incubated overnight at $4^{\circ} \mathrm{C}$. Samples were then washed 3 times for $10 \mathrm{~min}$ each in washing solution (1\% heatinactivated goat serum and $0.1 \%$ Triton X-100 in PBS) followed by incubation in the blocking solution with the secondary antibody (FITC-conjugated goat anti-rabbit antibody, 1:1000, Jackson Immunochemicals). Samples were washed 3 times for 10 min each in washing solution and mounted for confocal microscopy.

\section{Migration assay}

Gonads and mesonephroi from $11.5 \mathrm{dpc}$ CD1 or GFP or Ptch ${ }^{\text {LacZ }}$ embryos were separated. A CD1 XY gonad was assembled with a GFP or a $P_{t c h}^{\text {LacZ }}$ mesonephros and cultured on an agar block for $48 \mathrm{~h}$ as described (Martineau et al. 1997). Images were obtained using a Leica MZFLIII dissecting microscope with a GFP filter.

\section{$\beta$-gal stain}

Samples were washed in PBS and fixed in 2\% paraformaldehyde for $20 \mathrm{~min}$ at room temperature. Samples were then rinsed in washing solution ( $2 \mathrm{mM} \mathrm{MgCl}, 0.02 \%$ Nonidet P-40 in PBS), incubated overnight at $37^{\circ} \mathrm{C}$ in $\beta$-gal stain $(1 \mathrm{mg} / \mathrm{mL} \mathrm{X}$-gal, 200 $\left.\mathrm{mM} \mathrm{K}_{3} \mathrm{Fe}(\mathrm{CN})_{6}, 200 \mathrm{mM} \mathrm{K}_{4} \mathrm{Fe}(\mathrm{CN})_{6}\right)$, washed, and postfixed in $4 \%$ paraformaldehyde.

\section{Assay for proliferation and apoptosis}

To assay proliferation, gonad explants were fixed overnight in $4 \%$ paraformaldehyde in PBS at $4^{\circ} \mathrm{C}$ immediately after culture. Samples were processed and cut into $10-\mu \mathrm{m}$ frozen serial sections as described (Karl and Capel 1998) and stained immunocytochemically for a proliferation marker, phosphorylated Histone $\mathrm{H} 3$ (pHH3). The primary antibody was a rabbit polyclonal antibody against pHH3 (1:1000; Upstate Biotechnology) and the secondary was an FITC-conjugated goat anti-rabbit antibody (1: 500, Jackson Immunochemicals). pHH3-positive cells from 10 serial sections of each gonad $(n=5)$ were counted and subjected to statistical analysis. To assay apoptosis, gonad explants were cultured in $1 \mathrm{~mL}$ medium with $2 \mu \mathrm{L}$ of LysoTracker Red DND99 (Molecular Probes) for an additional $30 \mathrm{~min}$ at the end of 24-h of culture. Gonad explants were washed 3 times in PBS, fixed overnight in $4 \%$ paraformaldehyde in PBS at $4{ }^{\circ} \mathrm{C}$, and mounted for confocal imaging.

\section{Acknowledgments}

We sincerely thank Dr. Ann Clark, who initiated this collaboration; Christopher Tilmann, Jennifer Brennan, Jennifer Schmahl, Andrea Ross, Jordan Bachvarov, and Leo DiNapoli, who all contributed to useful discussions. For their generous gifts of materials, we thank Harold Erickson (laminin antibody), Ken-ichirou Morohashi (SF1 antibody), Keith Parker (Scc probe), and Matthew Scott (Ptch ${ }^{t m 1 M p s}$ mice). This work was supported by grants to B.C. from the NIH (HD39963-04) and a postdoctoral fellowship from the Lalor Foundation to H.Y.

The publication costs of this article were defrayed in part by payment of page charges. This article must therefore be hereby marked "advertisement" in accordance with 18 USC section 1734 solely to indicate this fact.

\section{References}

Albrecht, K.H. and Eicher, E.M. 2001. Evidence that Sry is expressed in pre-Sertoli cells and Sertoli and granulosa cells have a common precursor. Dev. Biol. 240: 92-107.

Ariyaratne, S.H.B., Mendis-Handagama, C.S., Hales, B.D., and Mason, I.J. 2000. Studies on the onset of Leydig precursor cell differentiation in the prepubertal rat testis. Biol. Reprod. 63: $165-171$.

Bitgood, M.J. and McMahon, A.P. 1995. Hedgehog and Bmp genes are coexpressed at many diverse sites of cell-cell interaction in the mouse embryo. Dev. Biol. 172: 126-138.

Bitgood, M.J., Shen, L., and McMahon, A.P. 1996. Sertoli cell signaling by Desert Hedgehog regulates the male germline. Curr. Biol. 6: 298-304.

Buehr, M., Gu, S., and McLaren, A. 1993. Mesonephric contribution to testis differentiation in the fetal mouse. Development 117: 273-281.

Bumcrot, D.A. and McMahon, A.P. 1996. Sonic hedgehog: Making the gradient. Chem. Biol. 3: 13-16.

Cann, G.M., Lee, J.W., and Stockdale, F.E. 1999. Sonic hedgehog enhances somite cell viability and formation of primary slow muscle fibers in avian segmented mesoderm. Anat. Embryol. (Berl) 200: 239-252.

Capel, B., Albrecht, K.H., Washburn, L.L., and Eicher, E.M. 1999. Migration of mesonephric cells into the mammalian gonad depends on Sry. Mech. Dev. 84: 127-131.

Carpenter, D., Stone, D.M., Brush, J., Ryan, A., Armanini, M. Frantz, G., Rosenthal, A., and de Sauvage, F.J. 1998. Characterization of two Patched receptors for the vertebrate hedgehog protein family. Proc. Natl. Acad. Sci. 95: 13630-13634.

Charrier, J.B., Lapointe, F., Douarin, N.M., and Teillet, M.A. 2001. Anti-apoptotic role of Sonic hedgehog protein at the early stages of nervous system organogenesis. Development 128: 4011-4020.

Clark, A.M., Garland, K.K., and Russell, L.D. 2000. Desert hedgehog (Dhh) gene is required in the mouse testis for formation of adult-type Leydig cells and normal development of peritubular cells and seminiferous tubules. Biol. Reprod. 63: $1825-1838$.

Clemens, J.W., Lala, D.S., Parker, K.L., and Richards, J.S. 1994. Steroidogenic factor-1 binding and transcriptional activity of the cholesterol side-chain cleavage promoter in rat granulosa cells. Endocrinology 134: 1499-1508.

Goodrich, L.V., Milenkovic, L., Higgins, K.M., and Scott, M.P. 1997. Altered neural cell fates and medulloblastoma in mouse Patched mutants. Science 277: 1109-1113.

Gubbay, J., Collignon, J., Koopman, P., Capel, B., Economou, A., Munsterberg, A., Vivian, N., Goodfellow, P., and LovellBadge, R. 1990. A gene mapping to the sex-determining region of the mouse Y chromosome is a member of a novel family of embryonically expressed genes. Nature 346: 245250.

Habert, R., Lejeune, H., and Saez, J.M. 2001. Origin, differentiation and regulation of fetal and adult Leydig cells. Mol. Cell Endocrinol. 179: 47-74.

Hadjantonakis, A.K., Gertsenstein, M., Ikawa, M., Okabe, M., 
and Nagy, A. 1998. Generating green fluorescent mice by germline transmission of green fluorescent ES cells. Mech. Dev. 76: 79-90.

Hatano, O., Takakusu, A., Nomura, M., and Morohashi, K. 1996. Identical origin of adrenal cortex and gonad revealed by expression profiles of Ad4BP/SF-1. Genes Cells 1: 663-671.

Hatano, O., Takayama, K., Imai, T., Waterman, M.R., Takakusu, A., Omura, T., and Morohashi, K. 1994. Sex-dependent expression of a transcription factor, $A d 4 B P$, regulating steroidogenic $\mathrm{P} 450$ genes in the gonads during prenatal and postnatal rat development. Development 120: $2787-$ 2797.

Hendzel, M.J., Wei, Y., Mancini, M.A., Van Hooser, A., Ranalli, T., Brinkley, B.R., Bazett-Jones, D.P., and Allis, C.D. 1997. Mitosis-specific phosphorylation of histone $\mathrm{H} 3$ initiates primarily within pericentromeric heterochromatin during G2 and spreads in an ordered fashion coincident with mitotic chromosome condensation. Chromosoma 106: 348-360.

Henrique, D., Adam, J., Myat, A., Chitnis, A., Lewis, J., and Ish-Horowicz, D. 1995. Expression of a Delta homologue in prospective neurons in the chick. Nature 375: 787-790.

Jost, A. 1947. Recherches sur la differenciation sexuelle de l'embryon de lapin. Arch. Anat. Microsc. Morphol. Exp. 36: 271-315.

Karl, J. and Capel, B. 1998. Sertoli cells of the mouse testis originate from the coelomic epithelium. Dev. Biol. 203: 323333.

Koopman, P., Gubbay, J., Vivian, N., Goodfellow, P., and LovellBadge, R. 1991. Male development of chromosomally female mice transgenic for Sry. Nature 351: 117-121.

Martineau, J., Nordqvist, K., Tilmann, C., Lovell-Badge, R., and Capel, B. 1997. Male specific cell migration into the developing gonad. Curr. Biol. 7: 958-968.

Merchant-Larios, H. and Moreno-Mendoza, N. 1998. Mesonephric stromal cells differentiate into Leydig cells in the mouse fetal testis. Exp. Cell Res. 244: 230-238.

Merchant-Larios, H., Moreno-Mendoza, N., and. Buehr, M. 1993. The role of the mesonephros in cell differentiation and morphogenesis of the mouse fetal testis. Int. J. Dev. Biol. 37: 407-415.

Moreno-Mendoza, N., Herrera-Munoz, J., and Merchant-Larios, H. 1995. Limb bud mesenchyme permits seminiferous cord formation in the mouse fetal testis but subsequent testosterone output is markedly affected by the sex of the donor stromal tissue. Dev. Biol. 169: 51-56.

Neumann, C. and Cohen, S. 1997. Morphogens and pattern formation. BioEssays 19: 721-729.

Nishino, K., Kato, M., Yokouchi, K., Yamanouchi, K., Naito, K., and Tojo, H. 2000. Establishment of fetal gonad/mesonephros coculture system using EGFP transgenic mice. I. Exp. Zool. 286: 320-327.

Nishino, K., Yamanouchi, K., Naito, K., and Tojo, H. 2001. Characterization of mesonephric cells that migrate into the XY gonad during testis differentiation. Exp. Cell Res. 267: 225-232.

Oppenheim, R.W., Homma, S., Marti, E., Prevette, D., Wang, S., Yaginuma, H., and McMahon, A.P. 1999. Modulation of early but not later stages of programmed cell death in embryonic avian spinal cord by sonic hedgehog. Mol. Cell Neurosci. 13: 348-361.

Palmer, S.J. and Burgoyne, P.S. 1991. In situ analysis of fetal, prepuberal and adult XX-XY chimaeric mouse testes: Sertoli cells are predominantly, but not exclusively, XY. Development 112: 265-268.

Paulson, J.R. and Taylor, S.S. 1982. Phosphorylation of histones 1 and 3 and nonhistone high mobility group 14 by an endog- enous kinase in HeLa metaphase chromosomes. I. Biol. Chem. 257: 6064-6072.

Pierucci-Alves, F., Clark, A.M., and Russell, L.D. 2001. A developmental study of the desert hedgehog-null mouse testis. Biol. Reprod. 65: 1392-1402.

Roberts, L.M., Hirokawa, Y., Nachtigal, M.W., and Ingraham, H.A. 1999. Paracrine-mediated apoptosis in reproductive tract development. Dev. Biol. 208: 110-122.

Rouiller, V., Gangnerau, M.N., Vayssiere, J.L., and Picon, R. 1990. Cholesterol side-chain cleavage activity in rat fetal gonads: A limiting step for ovarian steroidogenesis. Mol. Cell. Endocrinol. 72: 111-120.

Saka, Y. and Smith, J.C. 2001. Spatial and temporal patterns of cell division during early Xenopus embryogenesis. Dev. Biol. 229: 307-318.

Schmahl, J., Eicher, E.M., Washburn, L.L., and Capel, B. 2000 Sry induces cell proliferation in the mouse gonad. Develop ment 127: 65-73.

Strigini, M. and Cohen, S.M. 1999. Formation of morphogen gradients in the Drosophila wing. Semin. Cell Dev. Biol. 10: $335-344$.

Taipale, J., Chen, J.K., Cooper, M.K., Wang, B., Mann, R.K., Milenkovic, L., Scott, M.P., and Beachy, P.A. 2000. Effects of oncogenic mutations in Smoothened and Patched can be reversed by cyclopamine. Nature 406: 1005-1009.

Tilmann, K. and Capel, B. 1999. Mesonephric cell migration induces testis cord formation and Sertoli cell differentiation in the mammalian gonad. Development 126: 2883-2890.

Umehara, F., Tate, G., Itoh, K., Yamaguchi, N., Douchi, T., Mitsuya, T., and Osame, M. 2000. A novel mutation of desert hedgehog in a patient with $46, \mathrm{XY}$ partial gonadal dysgenesis accompanied by minifascicular neuropathy. Am. I. Hum. Genet. 67: 1302-1305.

Vainio, S., Heikkila, M., Kispert, A., Chin, N., and McMahon, A. 1999. Female development in mammals is regulated by Wnt-4 signaling. Nature 397: 405-409.

Vervoort, M. 2000. hedgehog and wing development in Drosophila: A morphogen at work? BioEssays 22: 460-468.

Yao, H.H.C. and Capel, B. 2002. Disruption of testis cords by cyclopamine or forskolin reveals independent cellular pathways in testis organogenesis. Dev. Biol. (in press).

Zucker, R.M., Hunter, E.S., and Rogers, J.M. 1999. Apoptosis and morphology in mouse embryos by confocal laser scanning microscopy. Methods 18: 473-480.

Zucker, R.M., Hunter, S., and Rogers, J.M. 1998. Confocal laser scanning microscopy of apoptosis in organogenesis-stage mouse embryos. Cytometry 33: 348-354. 


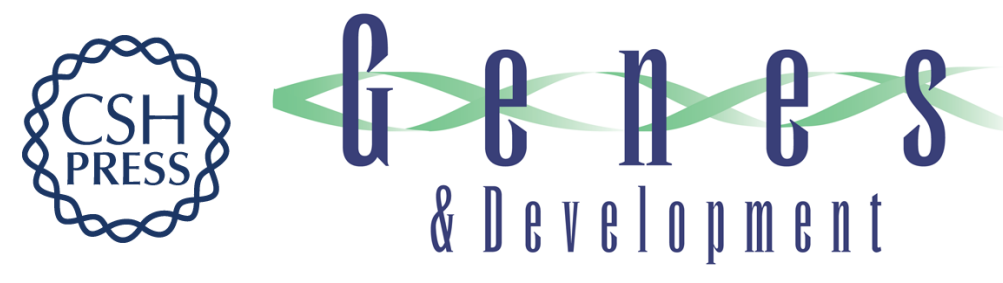

\section{Desert Hedgehog/Patched 1 signaling specifies fetal Leydig cell fate in testis organogenesis}

Humphrey Hung-Chang Yao, Wendy Whoriskey and Blanche Capel

Genes Dev. 2002, 16:

Access the most recent version at doi:10.1101/gad.981202

References

This article cites 50 articles, 9 of which can be accessed free at:

http://genesdev.cshlp.org/content/16/11/1433.full.html\#ref-list-1

\section{License}

Email Alerting

Receive free email alerts when new articles cite this article - sign up in the box at the top

Service right corner of the article or click here.

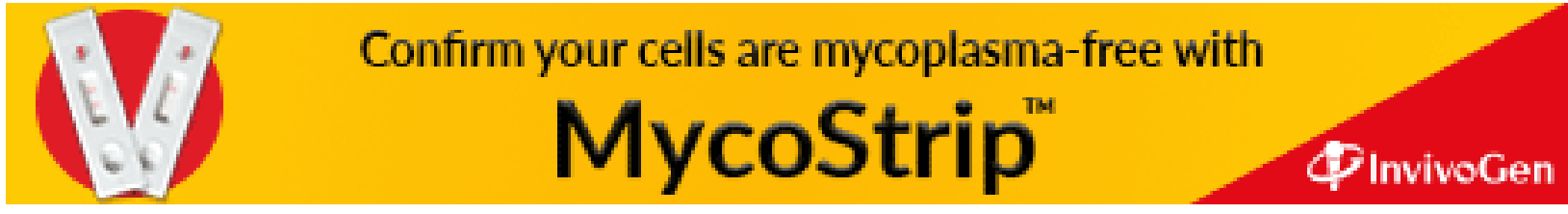

